\title{
Development and Evaluation of Manually Operated Seed-Cum-Fertilizer Drill for Ragi Sowing
}

\author{
Syed Mazara Ali ${ }^{*}$, K. H. Nagaraj ${ }^{2}$ and S. Kamala Bai ${ }^{2}$ \\ ${ }^{1}$ Farm Superintendent, Agriculture Research Station, \\ Pavagada, Tumkur district, Karnataka, India \\ ${ }^{2}$ University of Agricultural Sciences, GKVK, Bengaluru-560065, India \\ *Corresponding author
}

\section{A B S T R A C T}

Ke y w o r d s
Ragi, Farmers,
Bullock drawn
seed drill

Finger millet or Ragi is one of the most important minor millet abundantly grown in southern parts of Karnataka. It plays a significant role in livelihood of small and marginal farmers in Ramanagara district of Karnataka, South India. Farmers generally follow traditional sowing method in Ragi using bullock drawn seed drill where uniformity in spacing and depth cannot be maintained. Quantity of seeds required for sowing is also more in this traditional method. On the other hand, line sowing of Ragi is more accurate to save seed, maintaining plant population and to reduce the cost of sowing, weeding \& thinning. Therefore, a simple manually drawn three-row seed-cum-fertilizer drill for Ragi sowing was developed at KVK, Ramanagara and evaluated at farmers field conditions. Results revealed that, it ensured uniform germination and proper crop stand and facilitated other post sowing operations like weeding, thinning, plant protection measures, irrigation and harvesting of Ragi crop. The developed seed drill had 94.5 percent field efficiency, has reduced 65 percent of cost in sowing and 50 percent reduction in labour dependency compared to traditional method of sowing.

\section{Introduction}

Finger millet commonly called as Ragi is one of the main crop grown in Southern Karnataka. Popularity of ragi is due to its medicinal and nutritional value such as high fiber content which helps in slow digestion of food in the body. It is very helpful for diabetic patients (Yang et al., 2012). Ramanagara district in Karnataka is predominantly agriculture oriented district and Ragi is one of the major crops grown in the district in an area of 62326 ha. Traditional farming is being practiced in Ramanagara district while sowing the crop.

Bullock drawn operated seed drills are commonly used in farmer's field where too much drudgery is involved and also the cost of production of Ragi is quite high (Rs.2500/h) due to excess involvement of labour in sowing. Further, availability of 
bullocks during the crucial sowing season and its higher hiring cost is also a big constraint. Quantity of seeds consumed through traditional method of sowing is 10 to $15 \mathrm{kgs} /$ acre which is 2 to 3 times higher than the recommended dosage. Non-availability of labour and draught power in peak period accounts for higher expenditure with less productivity. The timeliness of operations has assumed greater significant in obtaining optimal yields from different crops, which has been possible by way of mechanization (Joginder Singh, 2006).

Considering the above facts, evaluation of manually operated farmer-friendly seed drill was undertaken through on-farm testing and the seed drill was developed to reduce the drudgery during sowing, increase the productivity of crop besides consuming less seed per acre and over all to reduce the cost of production in Ragi.

\section{Materials and Methods}

\section{Field trial}

Assessment of developed seed drill was conducted by taking on-farm testing in 25 numbers of farmers field located at different locations for the period of three years over an area of 5 ha. Treatments were $\mathrm{T}_{1}$ - Farmers Practice (Bullock drawn seed drill) and $\mathrm{T}_{2}-$ Manually operated seed drill with 3 seed bowls (Fig. 1- Manually operated seed drill).

Seeds and fertilizer were sown simultaneously by passing seed drill manually during single pass. Spacing of $30 \mathrm{~cm}$ was given between line to line and $10 \mathrm{~cm}$ between seed to seed. Seed and fertilizers were mixed manually prior to filling. Provision was also made for depth control. The field observations included Theoretical Field capacity (TFC), Actual Field capacity (AFC), Field efficiency, Plant population and Speed of operation. The following procedure was adopted for evaluating the performance of the seed drill.

\section{Theoretical field capacity (tfc)}

It is the rate of field coverage of the implement based on 100 percent of time at the rated speed and covering 100 percent of its rated width

$T \square$ eoretical Field Capacity $=\frac{W X S}{10}$

Where, W= Width of machine $(\mathrm{m}), \mathrm{S}=$ Speed $(\mathrm{km} / \mathrm{h})$

\section{Actual field capacity (afc)}

It is the actual performance of the machine during field operation. It is the quantum of work turned out by the seed drill.

\section{Field efficiency}

The field efficiency of the seed drill indicated the efficacy of the machine and operator, in reducing the time taken in turning and stoppage for adjustments. It was calculated by

Field Effeciency $(\%)=\frac{A F C}{T F C} \times 100$

Higher field efficiency indicated faster fields coverage in lesser time and hence reduced the cost of operation.

\section{Speed of operation}

For measuring forward speed of sowing equipment, the distance travelled by the machine in 15 seconds was measured and speed of travel was recorded in terms of $\mathrm{km} / \mathrm{h}$.

\section{Construction of equipment}

The Seed drill Developed consists of Handle, Cage wheel, Furrow opener, Blade and 
Metering drum. Cage wheel is made of high gauge SS (Stainless steel) which helps in giving better traction and grip during operation. Metering drums are made of high quality plastic. Hole of $5 \mathrm{~mm}$ diameter was made on drums. Two bushes are provided on each side of the seed box through which main shaft passes. The main shaft is driven through drive wheels.

Thus, the motion of the drive wheels through main shaft causes the seed box to rotate. When seed dispenser (Seed box) rotates, the seeds are fallen through hole provided in box in the furrow made by the furrow openers. The seeds are then covered by soil through a blade type covering device the provision of which is made. Technical details of seed drill are given in Table 1 .

\section{Calibration of seed drill}

The seed drill (Table 2) was calibrated as per IS 6316 (1993) test code. For calibration, the seed drill was jacked up and supported on its frame so that the wheels were free to rotate. A plain cloth was laid under each seed dispenser for collection of seeds. The seeds were cleaned and seed box-cum-seed dispenser of the drill was filled with cleaned Ragi seeds. The ground wheel of the drill was rotated manually for 50 revolutions at normal working speed and seeds collected were weighed. The test was repeated thrice at three fourth capacity of the seed box-cum-seed dispenser (metering mechanism) for Ragi seeds.

\section{Results and Discussion}

Results of the calibration are shows in Table 2 . The variation between discharge rates is in the range of 0.13 to $0.16 \mathrm{~g}$ from different rows from different replications and there was little variation in seed rate. Average seed rate was $10.8 \mathrm{~kg} / \mathrm{h}$. This seed rate is significantly lower than farmers practice which is 18 to $20 \mathrm{~kg} / \mathrm{h}$. Thus, this reduced seed rate may help in reducing the total cost of seeding as well as the cost in thinning and weeding operations. These results are in accordance with Shambu et al., (2019).

The results of the farm trials are presented in Table 3. The Theoretical field capacity (TFC) of $\mathrm{T}_{2}$ treatment was found to be 0.148 and Actual field capacity (AFC) was 0.14. Whereas in farmers practice AFC was 0.09 and TFC was 0.096. Field capacity is higher in $\mathrm{T}_{1}$ treatment than $\mathrm{T}_{2}$ treatment. This may be due to the reason that farmers use bullock power for sowing which is generally faster than sowing with developed seed drill.

But uniformity in sowing and seed rate is effectively done through the use of developed manually operated seed drill which is very difficult in farmers practice. Field efficiency of $\mathrm{T}_{2}$ treatment was 94.5 which is better than $\mathrm{T}_{1}$. Similar results were found by Shambu et $a l$, in 2019. Plant population and number of tillers /plant are better in $T_{2}$ treatment than $T_{1}$. Manually operated seed drill has reduced 65 percent of cost in sowing as compared with bullock drawn seed drill. Data shows that grain yield increased non-significantly in $T_{2}$ with $32.75 \mathrm{q} / \mathrm{h}$ as compared with $\mathrm{T}_{1}$ which is $31.1 \mathrm{q} / \mathrm{h}$

\section{Economic analysis}

The economic analysis presented in Table 4 shows that there was 5.1 percent reduction in the cost of production of Ragi and 5.3 percent increase in gross return when manually operated ragi seed drill was used. Similarly net returns obtained using the developed seed drill was found to be 10.5 percent higher than the farmers practice. $\mathrm{BC}$ ratio obtained in $\mathrm{T}_{2}$ treatment was found to be better with 1:3.3 as compared to traditional practice (T1) (Fig. 2). 
Table.1 Technical Specification of the manually operated seed-cum-fertilizer drill

\begin{tabular}{|l|l|c|}
\hline Sl.No & Particulars & Specifications \\
\hline $\mathbf{1}$ & L x B x H & 2000 x 1040 x 700 mm \\
\hline $\mathbf{2}$ & Row x Seed Spacing & $300 \mathrm{~mm}$ x 100 mm \\
\hline $\mathbf{3}$ & Effective width & $900 \mathrm{~mm}$ \\
\hline $\mathbf{4}$ & No .of Drums-Seeds & 3 \\
\hline $\mathbf{5}$ & Fertilizer (DAP) & 2 \\
\hline $\mathbf{6}$ & Drum capacity-Seeds & $450 \mathrm{~g} / \mathrm{drum}$ \\
\hline $\mathbf{7}$ & Fertilizer & $500 \mathrm{~g} / \mathrm{drum}$ \\
\hline $\mathbf{8}$ & Metering hole dia & $5 \mathrm{~mm}$ \\
\hline $\mathbf{9}$ & Weight of implement & $7.5 \mathrm{~kg}$ \\
\hline
\end{tabular}

Table.2 Laboratory calibration of manually operated seed-cum-fertilizer drill

\begin{tabular}{|c|c|c|c|c|c|c|c|}
\hline \multirow[t]{2}{*}{$\begin{array}{l}\text { Crop } \\
\text { Type }\end{array}$} & \multirow[t]{2}{*}{ Replication } & \multicolumn{3}{|c|}{$\begin{array}{c}\text { Wt. of Seeds dropped in } 50 \\
\text { revolution }\end{array}$} & \multirow[t]{2}{*}{$\begin{array}{l}\text { Total wt. } \\
\text { (g) }\end{array}$} & \multirow{2}{*}{$\begin{array}{c}\text { Seed } \\
\text { rate } \\
(\mathbf{K g} / \mathbf{h})\end{array}$} & \multirow{2}{*}{$\begin{array}{c}\text { Avg } \\
\text { Seed } \\
\text { rate } \\
(\mathrm{Kg} / \mathrm{h})\end{array}$} \\
\hline & & $\begin{array}{l}1^{\text {St }} \text { Row } \\
\text { (g) }\end{array}$ & $\begin{array}{l}2^{\text {nd }} \text { Row } \\
(\mathrm{g})\end{array}$ & $\begin{array}{l}3^{\text {rd }} \text { Row } \\
\text { (g) }\end{array}$ & & & \\
\hline \multirow[t]{3}{*}{ Ragi } & $\mathrm{R} 1$ & 0.15 & 0.15 & 0.14 & 0.44 & 10.8 & \multirow[t]{3}{*}{10.8} \\
\hline & $\mathrm{R} 2$ & 0.14 & 0.16 & 0.16 & 0.46 & 10.5 & \\
\hline & R3 & 0.18 & 0.13 & 0.15 & 0.46 & 11.1 & \\
\hline
\end{tabular}

Table.3 Field evaluation of manually operated seed-cum-fertilizer drill

\begin{tabular}{|c|c|c|c|c|c|}
\hline \multirow[t]{2}{*}{ SI.No } & \multirow[t]{2}{*}{ Parameters } & \multicolumn{2}{|c|}{$\begin{array}{l}\text { T }_{1} \text { - Farmers Practice (Bullock } \\
\text { drawn seed drill) }\end{array}$} & \multicolumn{2}{|c|}{$\begin{array}{l}T_{2} \text { - Manually operated seed } \\
\text { drill with } 3 \text { seed bowls }\end{array}$} \\
\hline & & AFC & TFC & AFC & TFC \\
\hline 1 & Field capacity (ha/hr) & 0.09 & 0.096 & 0.14 & 0.148 \\
\hline 2 & Field efficiency (\%) & \multicolumn{2}{|c|}{93.7} & \multicolumn{2}{|c|}{94.5} \\
\hline 3 & $\begin{array}{l}\text { Plant population } / \mathrm{m}^{2} \\
\text { (No.) }\end{array}$ & \multicolumn{2}{|c|}{31} & \multicolumn{2}{|c|}{34.5} \\
\hline 4 & No.of tillers/plant & \multicolumn{2}{|c|}{3.2} & \multicolumn{2}{|c|}{5.5} \\
\hline 5 & $\begin{array}{l}\text { Cost of Sowing } \\
\text { Rs./ha }\end{array}$ & \multicolumn{2}{|c|}{1575} & \multicolumn{2}{|c|}{550} \\
\hline 6 & Seed Rate $(\mathrm{kg} / \mathrm{h})$ & \multicolumn{2}{|c|}{18} & \multicolumn{2}{|c|}{11} \\
\hline 7 & Grain yield $(\mathrm{q} / \mathrm{h})$ & \multicolumn{2}{|c|}{31.1} & \multicolumn{2}{|c|}{32.75} \\
\hline
\end{tabular}

Table.4 Economic analysis of manually operated seed-cum-fertilizer drill

\begin{tabular}{|c|c|c|c|c|c|c|c|c|c|c|}
\hline \multicolumn{2}{|c|}{$\begin{array}{c}\text { Grass cost } \\
(\mathrm{Rs} / \mathrm{h})\end{array}$} & \multirow[t]{2}{*}{$\begin{array}{c}\% \\
\text { Change }\end{array}$} & \multicolumn{2}{|c|}{$\begin{array}{l}\text { Gross Return } \\
\text { (Rs/h) }\end{array}$} & \multirow[t]{2}{*}{$\begin{array}{c}\% \\
\text { Change }\end{array}$} & \multicolumn{2}{|c|}{$\begin{array}{l}\text { Net return } \\
\text { (Rs/h) }\end{array}$} & \multirow{2}{*}{$\begin{array}{c}\% \\
\text { Change }\end{array}$} & \multicolumn{2}{|c|}{ B:C ratio } \\
\hline $\mathbf{T}_{1}$ & $\mathrm{~T}_{2}$ & & $\mathrm{~T}_{1}$ & $\mathrm{~T}_{2}$ & & $\mathrm{~T}_{1}$ & $\mathrm{~T}_{2}$ & & $\mathrm{~T}_{1}$ & $\mathrm{~T}_{2}$ \\
\hline 36700 & 34900 & 5.1 & 111960 & 117900 & 5.3 & 75260 & 83000 & 10.5 & 3.0 & 3.3 \\
\hline
\end{tabular}




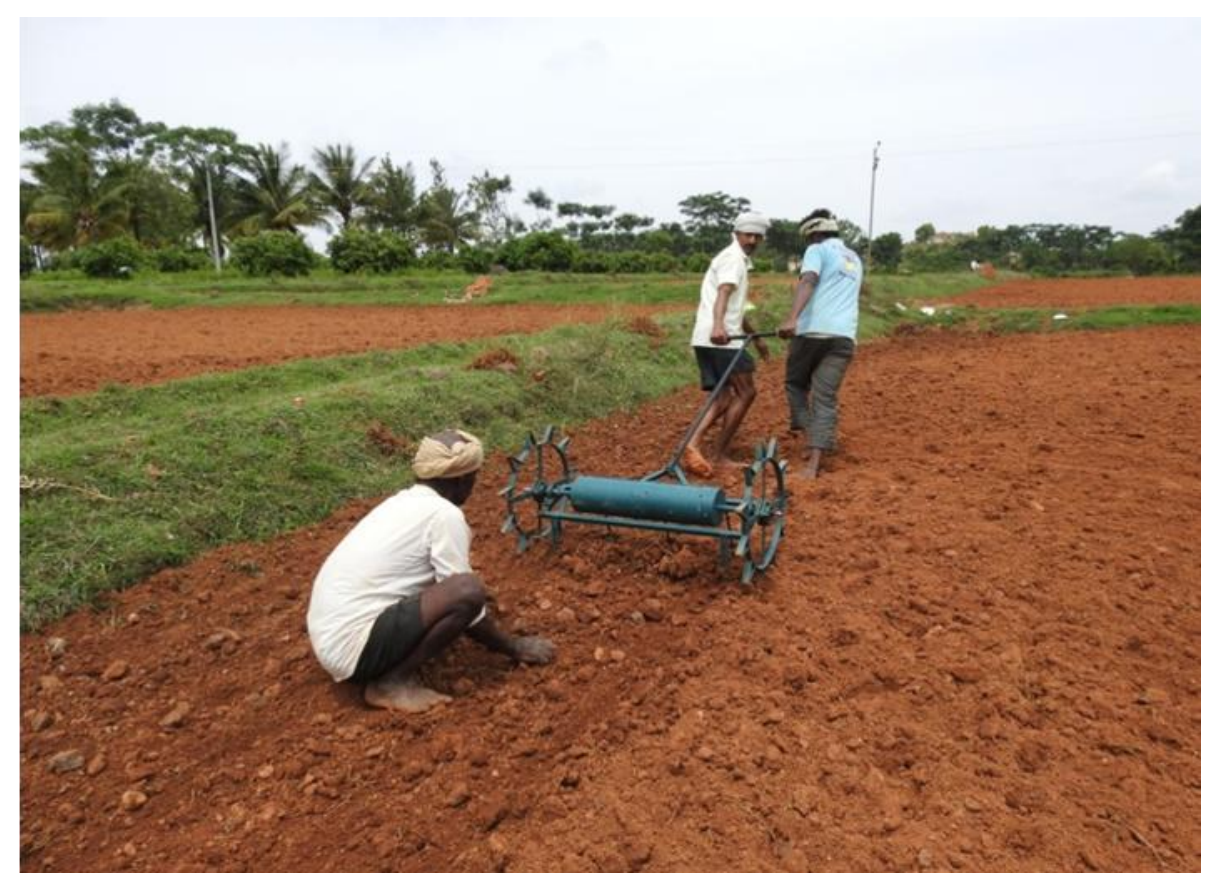

Fig.1 Hand operated Seed-cum-Fertilizer Drill in operation

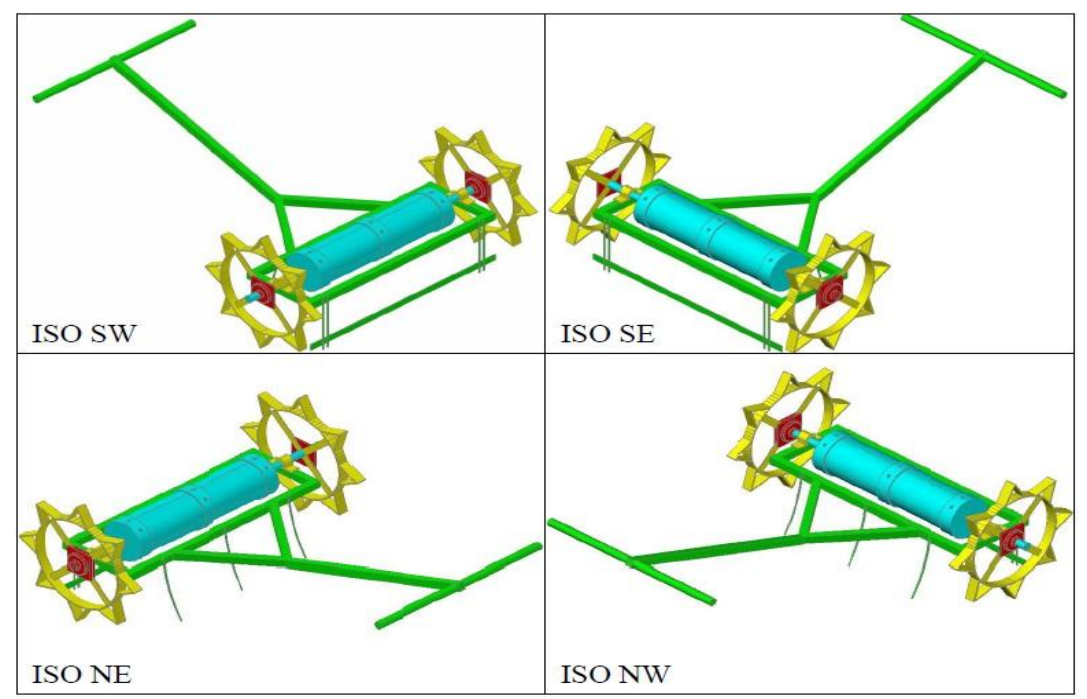

Fig.2 Isometric view of Seed-cum-Fertilizer Drill

This is due to reduction in labour cost during operation since sowing by using developed seed drill utilizes only two labours whereas farmers practice require around 4-5 labours. Similar results were obtained by Kahloon et $a l$., in 2012. Timely sowing and availability of labour are the most crucial factor in Ragi sowing. Developed seed drill not only reduces drudgery in sowing but also helps in reducing labour cost resulting in the increased returns to the small and marginal farmers. However, the developed Manually Operated Seed-CumFertilizer Drill for Ragi sowing has to be evaluated further by the Farm Universities in order to release for commercial adoption. 
References

India. $\quad \mathrm{http} / / /$

Anonymous 1993. Test Code for sowing www.researchgate.net/publication/2660 82375 equipment seed-cum-fertilizer drill. IS: 6316. Bureau of Indian Standards, Manak Bhawan, New Delhi.

Kahloon, M.H, Iqbal, M.F, Farooq M ,Liaqat Ali, Fiaz M and Ahmad I, 2012, A Comparison of conservation technologies and traditional techniques for sowing of wheat, The Journal of Animal and Plant Sciences, 22(3): 827830.

Singh Joginder. 2006. Scope, progress and constraints of farm mechanization in

Shambhu, Vidya and Thakur, Abhay, 2019, Laboratory and field performance of manual seed drill for sowing jute and tiny seeds. Indian Journal of Agricultural Sciences. 89:129-132.

Yang X, Wan Z, Perry L, Lu H, Wang Q, Hao C, Li J, Xie F, Yu J, Cui T, Wang T, Li M and Ge Q H. 2012, Early millet use in northern China, Proceedings, National Academy of Sciences, USA:15.

\section{How to cite this article:}

Syed Mazara Ali, K. H. Nagaraj and Kamala Bai, S. 2020. Development and Evaluation of Manually Operated Seed-Cum-Fertilizer Drill for Ragi Sowing. Int.J.Curr.Microbiol.App.Sci. 9(04): 2946-2951. doi: https://doi.org/10.20546/ijcmas.2020.904.345 